\title{
University Library Services Development Discipline Problems and Optimization Strategies
}

\author{
Qingsong Zhang \\ Library \\ Jilin Agricultural University \\ Changchun,,China \\ 729738677@qq.com \\ $+8615604305161$
}

\author{
Xinyu Wang \\ Library \\ Jilin Agricultural University \\ Changchun,,China \\ lxy@jlau.edu.cn
}

\begin{abstract}
The University Library services are subject to deal with the inevitable choice of today's complex environment , but also the future direction of the University Library. In this paper, the necessity of university library services connotation construction of subjects were discussed, through the analysis of problems , put forward the corresponding countermeasures.
\end{abstract}

Keywords- Keywords: University Library; discipline services; connotation construction; optimization strategy; Quality of ServiceIntroduction

\section{INTRODUCTION}

With the rapid development of digital information resources, university teachers and students demand for library services also had a great change , as the management center college university library information resources, the need to constantly update the management philosophy, to adapt to changing user needs, and promote services provided by towards a single document services knowledge services. The discipline of knowledge management in library services, it is reasonable to configure and use the university library information resources to fully meet users' changing disciplines in information and knowledge needs.

\section{THE CONNOTATION OF A UNIVERSITY LIBRARY SERVICES AND CONSTRUCTION DISCIPLINES SIGNIFICANCE}

Zhang Xiaolin said: "The service is based on scientific subjects, rather than in accordance with the document workflow to organize scientific and technological information, to make information technology services disciplines rather than positions, thus enabling services rather than simple knowledge-based document retrieval and delivery ."

Discipline serves as an advanced concept of running the museum and a new service model, bound to go the way of content development, which should go outward expansion of the main road, gradually transformed into more attention to the construction and enrich the connotation of the road up, the past the number of type , scale , speed type to quality type , taste , benefit and improve service quality as the most important track. University Library to the path of connotation construction, improve service quality, has very important significance.

First, strengthening discipline connotation construction services , improve service quality, is the inevitable trend of development of University Library . Since the 1980s , the connotation of development road China became the dominant ideology of the library community , serving as the main university library content " service discipline " in the growing user demand for fine background and a lot of discipline information must go connotation construction of the road , and provide a strong guarantee for the teaching and research academic information ${ }^{[1]}$.

Secondly, strengthening discipline connotation construction services, improve service quality, is the inevitable product of innovative university library services . University Library to innovative services, and actively expand the scope of services, deepen service levels to meet the needs of science and research development. Construction of three-dimensional disciplines service system, be subject Services, University Library Service Innovation is the inevitable outcome is a necessary requirement of professional needs of user groups is the traditional reference to develop in depth, the inevitable result of active service to the direction of development.

Again, strengthening discipline connotation construction services, improve service quality, but also the university library to research libraries change to better serve the teaching and research services inevitable trend. Disciplines with a very large significance for the development of universities . Disciplines is key to creating a first-class research university. University Library to adapt to the development of higher education , in line to become the leading research libraries goals, adjust service orientation and service content, and disciplines to promote the university library 's own development

\section{UNIVERSITY LIBRARY SERVICES DEVELOPMENT DISCIPLINE PROBLEMS}

Refused to incomplete statistic, China's colleges universities in about $50 \%$ of the subjects had to carry out the service, although the faculty and students to meet the learning, teaching and research needs has made some achievements, but the overall situation is not satisfactory, the main problem there are several aspects .

A. disciplinary service model to follow suit, without regard to the actual school

The measure of a good or bad depends on the university 
library services can meet the needs of readers university library , rather than looking at it and how many old and new services. Some schools see other schools building characteristics repository, they would be replicated; see other schools, construction of information sharing space, but also be copied, without regard to whether there is a corresponding demand for readers, nor consider themselves whether there is a more mature infrastructure, staffing and financial support, the results of a waste of resources, to achieve the desired effect is no embassy staff is greatly dampened the enthusiasm.

\section{B. Subject service force shortage, weak service}

Subject Librarian's responsibilities include: Responsible for liaison between the library and faculty , academic information resources services, disciplinary information literacy education, library resources and reference services building $^{[2]}$. Subject Librarian System , discipline Services is a new thing, is in the exploration and exploratory stage, and with the traditional library services are quite different way , so in many schools, discipline is not even the service user 's Hall Museum members approved, subject librarians can not effectively coordinate with other departments, only to struggle alone, and highly exclusive.

\section{Subject Librarian is not high quality, limited service capacity}

In foreign university library, academic librarians have a more strict access system. Under normal circumstances, subject librarians need a master's in library and information disciplines and professional backgrounds, and in most domestic libraries, academic librarians ability uneven, though they are the backbone of the museum of technology and business , but really only understanding of professional , business and proficient library subject Librarians are rare. Therefore, the current domestic services focused on the subject librarian in touch with their counterparts in the basic faculties , resources, advice collect, collate , freshman admission education, education and other basic information retrieval services , and professional information retrieval for faculties counterparts, SDI service, academic and other aspects of dynamic analysis of deep-level services are rarely carried out ${ }^{[3]}$.

\section{D. disciplinary responsibilities are not clear, the service is not efficient}

As domestic discipline services to carry out a short time, most of the responsibility for discipline university librarian just a simple description, or there is a simple Provisional Measures, yet form a more perfect norms and rules, resulting in the work of subject librarians can not be quantified , statistics and assessment, be implemented entirely in accordance with the wishes of subject librarians , the results of some subject librarian tired, but nothing some subject librarian .

\section{STRATEGIES TO ENHANCE THE QUALITY OF SERVICE DISCIPLINES UNIVERSITY LIBRARY}

\section{A. Subject to strengthen team building}

Team work is to provide quality service guarantee. University Library Services team discipline is not simply composed by the subject librarian, the library with its counterpart departments, subject matter experts in close communication and cooperation, between teaching and research staff. In the subject service, you need to be established between faculty and students, academic librarians, information resources organic links, library information resources and services through the organic integration, through the role of subject librarians bridge to construct a more complete disciplinary service system for faculty and students to provide targeted support and ancillary services in all stages of teaching and research.

\section{B. Subject to build web-based technology services platform}

Discipline service platform is to contact the user and subject librarian discipline bridge interaction between the two sides of the space and place, but also the external manifestation of disciplinary service system. Subject to further deepen the services needed in the principle of resources, technology, service of unity, network technology platform as support to build a user-oriented service platform integrated disciplines ${ }^{[4]}$. Network integration service platform should be subject not only to reveal a collection of academic resources entities, but also to discipline navigation links to virtual resources ; organizational resource management platform both disciplines, but also the discipline of information publishing platform ; while the librarians , users and common communication a platform

\section{Subject to establish mechanisms for integration of interactive services}

Full of vitality and interaction mechanisms established to carry out the cornerstone of academic services is vibrant. In the knowledge environment in the pan, cutting service to get rid of the traditional passive service concept, from the user's position and needs to strengthen ties with the faculty will integrate all aspects of academic service line, embedding the research process, providing discipline of personalized, knowledgeable and ubiquitous service for interdisciplinary research to provide a full range of information security environment. Subject Librarian to get out of the library and into the various faculties, through cooperation with school faculties, improve the construction of the various disciplines of professional literature resources, improve the level of discipline construction. Related disciplines should be involved in activities subject librarian faculty organizations to keep abreast of developments in related disciplines, the latest resources and services in a timely manner and push notification library, Novelty initiative to undertake, on behalf of the check on behalf of inspection work, to carry out a given topic and tracking, personalized service 
disciplines.

D. Subject service innovation management system

Sustainable development requires discipline service innovation management system. University Library need to establish a scientific management system, including financial security system, personnel management mechanism, qualification certification system, to form a subject librarian selection, evaluation and appropriate disciplinary norms. Library services of university disciplines need foreign experience, innovation management system, for example, subject librarians achieve qualification, certificates; establish a user-oriented subject librarian appraisal system; establish relevant training mechanism to discipline reference librarians to develop a deeper level of customer service model $^{[5]}$.

\section{CONCLUSION}

In short, the library service is an important direction of discipline as a university library services, its content and the way services are in the process of continuous development and innovation, with the discipline of building services team to build discipline and service network platform services fusion of disciplines build mechanisms and innovative service management system disciplines, quality and content of academic services is bound to be constantly enriched and improved.

\section{REFERENCES}

[1] Song Haiyan. Service Models and Research. Ubiquitous Knowledge Environment Library Disciplines Dynamic Mechanism ---. Intelligence Theory and Explore the Learning Space Exploration Based Converged Services [J]. Information Studies:Theory \& Application, 2010 (7) :60-62.

[2] Liu Ying, Huang Chuanhui. Embedded User Environment: a New Direction Library Subject Service[J]. Document,Information \& Knowledge, 2010 (1): 54.

[3] Wang Xiaoli. Library Disciplines Foreign Universities Librarian Service Model [J]. Library and Information Service, 2008 (2) :20-23.

[4] Li Yuyan. "Scholar's Lab" Discipline University Library Service Innovation Inspiration [J]. Modern Information, 2010 (3) :148-149, 153.

[5] Zhu Xiaoxiao. Construction of University Library Disciplinary Literature Information Service Platform [J]. Information and Documentation Services, 2011 (4) :84-86. 